\title{
Microbiological and Physicochemical Characteristics of Three Types of "Soumbara" from Seeds of African Locust Bean in Korhogo Markets, Côte d'Ivoire
}

\author{
Ollo Kambire $\mathbb{D}^{1},{ }^{1}$ Konan Mathurin Yao, ${ }^{1}$ Andrée Emmanuelle Sika, ${ }^{2}$ Aminata Coulibaly, ${ }^{1}$ \\ Zamble Bi Irie Abel Boli $\mathbb{D}^{2}{ }^{2}$ and Rose Koffi-Nevry ${ }^{2}$ \\ ${ }^{1}$ Department of Biochemistry and Genetics, Peleforo Gon Coulibaly University, BP 1328 Korhogo, Côte d'Ivoire \\ ${ }^{2}$ Department of Food Science and Technology, Laboratory of Biotechnology and Food Microbiology, Nangui Abrogoua University, \\ 02 BP 801 Abidjan, Côte d'Ivoire
}

Correspondence should be addressed to Ollo Kambire; kam_ollo@yahoo.fr

Received 5 January 2021; Revised 25 March 2021; Accepted 30 March 2021; Published 12 April 2021

Academic Editor: Jirapornchai Suksaeree

Copyright (c) 2021 Ollo Kambire et al. This is an open access article distributed under the Creative Commons Attribution License, which permits unrestricted use, distribution, and reproduction in any medium, provided the original work is properly cited.

\begin{abstract}
"Soumbara" is a fermented product sold in the markets of several West African countries. In the markets, it is sold in several formats (granulated, powder, and paste). The objective of this study was to evaluate the microbiological and physicochemical characteristics of these three types of "Soumbara" sold in the Korhogo markets. For this purpose, a preliminary survey followed by a sampling of 54 samples of "Soumbara" was carried out. The microorganism load count was carried out according to microbiological standards. The $\mathrm{pH}$, titratable acidity, and moisture content were measured, respectively, with a $\mathrm{pH}$ meter, by dosing with sodium hydroxide solution and by differential weighing after passing the sample through the oven. The $\mathrm{pH}$ of the different samples is around 6. The moisture content is higher in "Soumbara" paste (20-24.7\%) than in powdered (7.3-9.3\%) and granulated (8.6-10.7\%) "Soumbara." The acidity rates are between 0.07 and $0.13 \%, 0.2$ and $0.3 \%$, and 0.08 and $0.1 \%$, respectively, for the granulated, powder, and paste types. Mesophilic aerobic germ loads $\left(6.17-8.38 \log _{10} \mathrm{cfu} / \mathrm{g}\right)$ for all three types of "Soumbara" are above the standard. Total coliform (1.13-2.96 $\left.\log _{10} \mathrm{cfu} / \mathrm{g}\right)$, mould $\left(0.86-2.52 \log _{10} \mathrm{cfu} / \mathrm{g}\right)$, and yeast (0.33-1.53 $\log _{10} \mathrm{cfu} / \mathrm{g}$ ) loads are below standard. The microbiological quality of the three types of "Soumbara" is unsatisfactory. Overall, "Soumbara" powder is the most contaminated, followed by granulated and paste "Soumbara." "Soumbara" must be added during culinary preparations in order to avoid possible public health problems.
\end{abstract}

\section{Introduction}

Food is a fundamental need for life. Agriculture, animal husbandry, and fishing provide humans with a variety of products that must be preserved over a long period of time. However, there are great disparities in food availability, particularly in sub-Saharan Africa where food insecurity, galloping population growth, and unbridled urbanization make people fear the worst for the future [1]. To this end, rapid urbanization in West Africa is contributing to the development of a processing and marketing sector for local agricultural products, essentially artisanal [2]. During the processing of these local products, a process of natural fermentation of protein and oil seeds takes place, particularly those of baobab (Adansonia digitata), groundnut (Arachis hypogaea), Hibiscus sabdariffa, soybean (Glycine max) and an African locust bean (Parkia biglobosa) [3, 4]. The fermentation of seeds of the Parkia biglobosa species produces a condiment that is one of the most important resources for food security, especially in times of food shortage and drought, and a resource of important socioeconomic and cultural values for local populations [5]. The fermentation of Parkia biglobosa seeds carried out by the Bacillus genus is an alkaline fermentation. This condiment is known in West Africa as "Soumbara" in Côte d'Ivoire, "soumbala" in Burkina Faso and Mali, "dawa-dawa" in Niger and Nigeria, and "nététu" in Benin and Senegal [6-9]. In most West African countries, "soumbala" is widely consumed by the rural and urban 
population. It has been accepted by public opinion that this condiment has a potential ability to regulate blood pressure, creating a growing craze for this condiment in cities $[4,10]$.

Produced however in an artisanal method and sold in the different markets in unhygienic conditions, the "Soumbara" could harbour microorganisms that can be pathogenic for humans and degrade the nutritional quality of this product. The "Soumbara" provides a favourable environment for the development of microorganisms due to its high water and nutrient content. Soumbara can be eaten after cooking in sauces. It can also be used to season dishes without cooking (especially powdered Soumbara). This act could create a health problem for the consumer if this condiment contains pathogens.

In Côte d'Ivoire, the main centres of production of "Soumbara" are located in the far north of the country where the resources of Parkia biglobosa are abundant. The production activities are still artisanal and devolved to women. According to De Angelis et al. [11], it is important to maintain local traditional foods which are often more environmentally sustainable than imported ones and have also a cultural meaning.

This study was undertaken in order to evaluate the physicochemical and microbiological characteristics of three types of "Soumbara" sold in different markets in the town of Korhogo.

\section{Material and Methods}

2.1. Survey. A preliminary survey was carried out among the "Soumbara" sellers in the different markets (five markets). This survey was aimed to collect information on the different types of "Soumbara" sold in the markets, the most sold type, the place of supply, the method of conservation, and hygiene. This survey was conducted in Korhogo, a city in the north of Côte d'Ivoire.

2.2. Sample Collection. The "Soumbara" production diagram contains several steps (Figure 1). In the different markets, "Soumbara" is sold unpackaged.

Samples were collected in three markets in the city of Korhogo, namely, Haoussabougou market $(\mathrm{MH})$, Petit Paris market (MPP), and Major market (MG) during the period from July to August 2020. The choice of these three markets is based on the effective presence of the different types of "Soumbara" (granulated, powder, paste). For the sampling, three (03) sellers were chosen at random in each market. Two samples of each type of "Soumbara" of approximately $100 \mathrm{~g}$ each were taken from each seller, making a total of 54 samples taken. All samples were taken in stomacher bags and transported to the laboratory in a cooler for analysis.

\subsection{Physicochemical Analysis}

2.3.1. $\mathrm{pH}$. The $\mathrm{pH}$ was determined according to the method proposed by N'goran-aw et al. [12]. Twenty (20) grams of each sample of "Soumbara" was added to $100 \mathrm{~mL}$ of distilled water. After filtration, the $\mathrm{pH}$ was read using a HANNA $\mathrm{pH}$ meter.

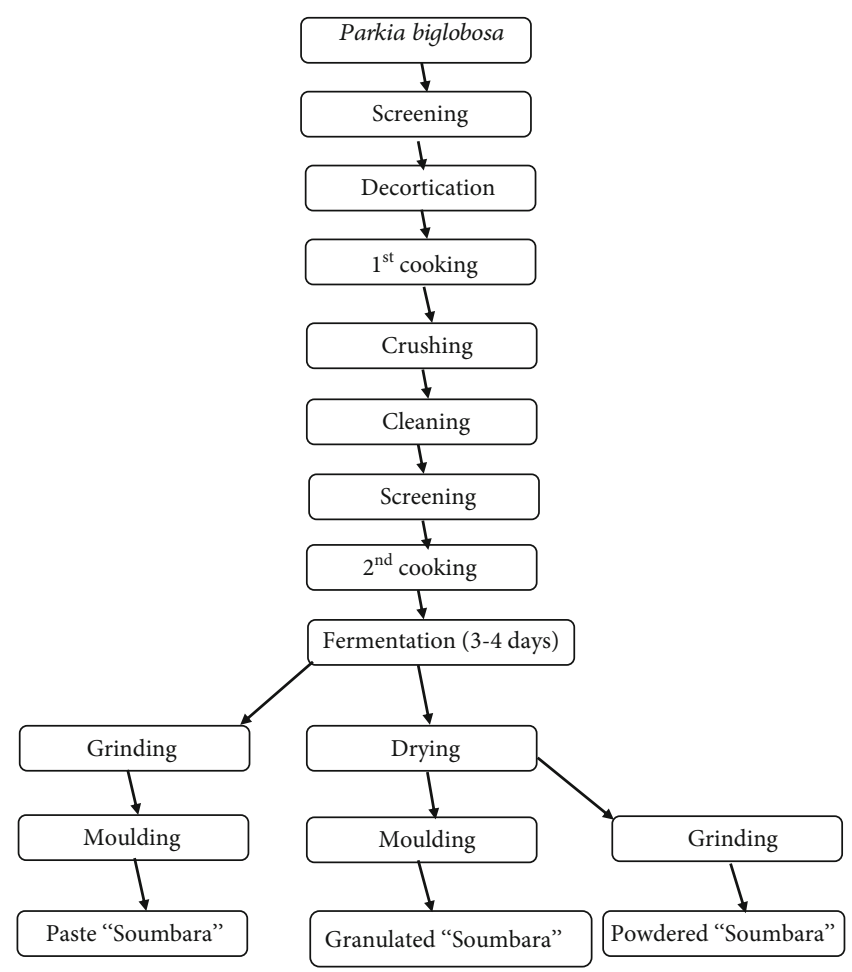

FIgURE 1: Diagram of the different production steps of the three types of "Soumbara".

2.3.2. Titratable Acidity. The titratable acidity was determined according to the method described by Amoa-awua et al. [13]. Ten grams of "Soumbara" was homogenized in $100 \mathrm{~mL}$ of distilled water. After filtration, 2 to 3 drops of $1 \%$ phenolphthalein were added to $10 \mathrm{~mL}$ of filtrate taken for the test sample, and the mixture was dosed with $0.1 \mathrm{~N}$ sodium hydroxide solution. The end of the dosage was marked by a pale pink colouring. The acidity rate expressed as a percentage was obtained according to the following formula:

$$
\% \text { titratable acidity }=\frac{\mathrm{V}(\mathrm{NaOH}) \times \mathrm{N}(\mathrm{NaOH}) \times 0,09 \times 100}{\mathrm{~V}(\text { test sample })} .
$$

2.3.3. Moisture Content. The moisture content was determined by differential weighing after oven drying according to the AOAC method [14]. Five (5) grams of each sample was weighed (M1) and placed in a crucible. The crucible containing the sample (M2) was placed in the oven at $105^{\circ} \mathrm{C}$ for 24 hours and weighed after cooling in a dry place. This process is repeated at one-hour intervals several times until a constant mass (M3) was reached. The moisture content expressed as a percentage was determined according to the following formula:

$$
\mathrm{MC}=\frac{M 2(g)-M 3(g)}{M 1(g)} \times 100
$$

2.4. Microbiological Analysis. Sample preparation: ten (10) grams of each sample of "Soumbara" was taken aseptically 
and homogenized in a borosilicate bottle containing $90 \mathrm{~mL}$ of buffered peptone solution. From the suspension obtained, decimal dilutions have been performed. Mesophilic aerobic germ count was performed on Plate Count Agar. The inoculated Petri dishes were incubated at $37^{\circ} \mathrm{C} / 24$ hours. The total coliforms count was carried out on the VRBL. Incubation of the Petri dishes was carried out at $35^{\circ} \mathrm{C}$ for 24 hours. Dichloran Rose Bengal Chloramphenicol agar was used for the enumeration of yeasts and moulds. The different microbial loads expressed in cfu/g have been calculated according to the formula ISO 7218 [15]:

$$
\mathrm{N}(\mathrm{cfu} / \mathrm{g})=\frac{\Sigma \mathrm{C}}{(\mathrm{n} 1+0, \ln 2) \cdot \mathrm{d} \cdot \mathrm{V}}
$$

2.5. Statistical Analysis. The analysis of variance (one-factor ANOVA) was performed with the Statistica software version 7.1 at the significance level $(\alpha=0.05)$. In case of significant difference between the parameters studied, the ranking of the means is done according to the Newman-Keuls test.

\section{Results}

3.1. Survey. In total, three types of "Soumbara" have been identified. These three types are sold simultaneously in three of the five markets surveyed. These are major market, Haoussabougou market and Petit paris market. Only two types are sold in the Soba and Sinistré markets. The type of "Soumbara" most requested by consumers is powdered "Soumbara" $(62.4 \%)$ followed by granulated "Soumbara" (34.72\%). Soumbara paste is the least requested (2.86\%). All the saleswomen buy their products from the producers and take more than a day to sell their stock. At all the saleswomen, the unsold "Soumbara" is stored in the store. During marketing, the "Soumbara" is not protected by any of the saleswomen surveyed (Table 1).

3.2. $p H$. The averages obtained ranged from 6.05 to 6.8 . The lowest averages were obtained in "Soumbara" powder, but compared to the averages of the other two types (paste, granulated), there is no significant difference $(P>0.05)$ (Table 2$)$.

3.3. Titratable Acidity. The average of titratable acidity of the samples of granulated "Soumbara" $(0.07-0.13 \%)$ is close to that of "Soumbara" paste $(0.08-0.1 \%)$. The highest percentages of titratable acidity were recorded in the samples of "Soumbara" powder (0.2-0.3\%). However, apart from the acidity of the samples of "Soumbara" powder from the major market, which stands out significantly $(P<0.05)$, no significant difference was recorded between the other titratable acidity values (Table 3 ).

3.4. Moisture Content. The moisture content obtained was between 7.3 and $24.7 \%$. The most important moisture contents $(P<0.05)$ were recorded in the samples of "Soumbara" paste. The lowest rate $(7.3 \%)$ was measured in samples of "Soumbara" powder. There is no significant difference between the values of granulated "Soumbara" and "Soumbara" powder (Table 4).

\subsection{Microbiological Analysis}

3.5.1. Mesophilic Aerobic Germ. Mesophilic aerobic germ loads in the different types of "Soumbara" range from 6.17 to $8.38 \log _{10} \mathrm{cfu} / \mathrm{g}$. They were between 6.41 and $8.38 \log _{10}$ cfu/g for granulated "Soumbara," 6.94 and $7.74 \log _{10} \mathrm{cfu} / \mathrm{g}$ for powdered "Soumbara" and between 6.17 and $8.74 \log _{10}$ cfu/g for paste "Soumbara." The majority of the significant charges were recorded in the granulated type. The loads of the three "Soumbara" types obtained in the samples of the major market were higher $(P>0.05)$ than those of the other two markets. There was no significant difference $(P>0.05)$ in loads from one type to another. All loads were above the limit $(M)$ value of $6 \log _{10} \mathrm{cfu} / \mathrm{g}$ (Table 5).

3.5.2. Total Coliforms. The loads were between 1.13 and 2.96 $\log _{10} \mathrm{cfu} / \mathrm{g}$ for all types. For each type of "Soumbara," the loads were between 1.71 and 2.25, 1.86 and 2.96, and 1.13 and $1.64 \log _{10} \mathrm{cfu} / \mathrm{g}$ for the granulated, powdered, and paste types, respectively. The most important loads were obtained in the powdered type; however, there is no significant difference between these loads and those of the other two "Soumbara" types. For all types of "Soumbara," the loads are lower than the limit $(M)$, which was $3 \log _{10} \mathrm{cfu} / \mathrm{g}$ (Table 6).

3.5.3. Yeasts and Moulds. The mould loads of the different types of "Soumbara" were between 0.86 and $2.52 \log _{10} \mathrm{cfu} / \mathrm{g}$. For each type, the loads were between 1.44 and $2.4,1.76$ and 2.25 , and 0.86 and $1.56 \log _{10} \mathrm{cfu} / \mathrm{g}$ for the granulated, powdered, and paste types, respectively. The powder type contains higher loads, but there were no significant differences $(P>0.05)$ between these and the other two types. All mould loads were below the limit $(M)$ value ( $4 \log _{10} \mathrm{cfu} / \mathrm{g}$ ) (Table 7$)$.

No yeast was counted in the three types of "Soumbara" of major market. For the other two markets, loads are between 0.33 and $1.53 \log _{10} \mathrm{cfu} / \mathrm{g}$. The samples of "Soumbara" powdered recorded the highest loads, but these were not significantly different from the other types. All yeast loads were below the value of the limit $(M)\left(4 \log _{10} \mathrm{cfu} / \mathrm{g}\right)$ (Table 8$)$.

\section{Discussion}

The range of $\mathrm{pH}$ obtained for the three types of "Soumbara" is between 6.05 and 6.8, and there is no significant difference from one type to another. These values are within the $\mathrm{pH}$ range obtained by Kambire et al. [16] in the "Soumbara" sold in the markets of the city of Abidjan. According to these authors, the acid $\mathrm{pH}$ obtained in the different samples of "Soumbara" is linked to the fermentation time (short). Indeed, for Parkouda et al. [17], the fermentation of African locust bean seeds is an alkaline fermentation. Thus, the low titratable acidity values obtained in this study could justify this predominance of alkaline fermentation.

The moisture content obtained in the samples of "Soumbara" in paste form are significantly higher than those of the other two types (granulated and powdered). This important difference in moisture content is linked to the production process of "Soumbara." Indeed, a drying stage is necessary during production to obtain granulated and powdered "Soumbara" unlike paste "Soumbara." The moisture content 
TABLE 1: Survey results.

\begin{tabular}{|c|c|c|c|c|c|c|}
\hline \multirow{2}{*}{ Parameters } & \multicolumn{6}{|c|}{ Name of markets } \\
\hline & Soba market & Sinistré market & Major market & Haoussabougou market & Petit Paris market & Average \\
\hline \multicolumn{7}{|l|}{ Soumbara type sold } \\
\hline Granulated & $100 \%$ & $100 \%$ & $85.7 \%$ & $100 \%$ & $100 \%$ & $97.14 \%$ \\
\hline Powder & $80 \%$ & $100 \%$ & $71.4 \%$ & $60 \%$ & $100 \%$ & $82.28 \%$ \\
\hline Paste & $0 \%$ & $0 \%$ & $85.7 \%$ & $60 \%$ & $25 \%$ & $34.14 \%$ \\
\hline \multicolumn{7}{|l|}{ Type requested } \\
\hline Granulated & $60 \%$ & $0 \%$ & $28.6 \%$ & $60 \%$ & $25 \%$ & $34.72 \%$ \\
\hline Powder & $40 \%$ & $100 \%$ & $57.1 \%$ & $40 \%$ & $75 \%$ & $62.42 \%$ \\
\hline Paste & $0 \%$ & $0 \%$ & $14.3 \%$ & $0 \%$ & $0 \%$ & $2.86 \%$ \\
\hline \multicolumn{7}{|l|}{ Supplying } \\
\hline Producer & $100 \%$ & $100 \%$ & $100 \%$ & $100 \%$ & $100 \%$ & $100 \%$ \\
\hline \multicolumn{7}{|l|}{ Sale } \\
\hline More than one day & $100 \%$ & $100 \%$ & $100 \%$ & $100 \%$ & $100 \%$ & $100 \%$ \\
\hline \multicolumn{7}{|c|}{ Storage unsold Soumbara } \\
\hline Store & $100 \%$ & $100 \%$ & $100 \%$ & $100 \%$ & $100 \%$ & $100 \%$ \\
\hline \multicolumn{7}{|c|}{ Protection during the sale } \\
\hline No protection & $100 \%$ & $100 \%$ & $100 \%$ & $100 \%$ & $100 \%$ & $100 \%$ \\
\hline
\end{tabular}

TABle 2: $\mathrm{pH}$ of the different types of "Soumbara."

\begin{tabular}{lccc}
\hline Market & Granulated & $\begin{array}{c}\mathrm{pH} \\
\text { Powder }\end{array}$ & Paste \\
\hline GM & $6.56 \pm 0.28^{\mathrm{a}}$ & $6.28 \pm 0.17^{\mathrm{a}}$ & $6.7 \pm 0.4^{\mathrm{a}}$ \\
MH & $6.8 \pm 0.03^{\mathrm{a}}$ & $6.05 \pm 0.38^{\mathrm{a}}$ & $6.7 \pm 0.43^{\mathrm{a}}$ \\
MPP & $6.8 \pm 0.25^{\mathrm{a}}$ & $6.3 \pm 0.18^{\mathrm{a}}$ & $6.6 \pm 0.52^{\mathrm{a}}$ \\
\hline
\end{tabular}

In row and column, the averages affected by the same letter are not significantly different at the $5 \%$ threshold according to the NewmannKeuls test. MH: Haoussabougou market; MPP: Petit Paris market; MG: Major market.

TABLE 3: Titratable acidity of the different types of "Soumbara."

\begin{tabular}{lccc}
\hline \multirow{2}{*}{ Market } & \multicolumn{3}{c}{ Titratable acidity (\% acidity) } \\
& Granulated & Powder & Paste \\
\hline MG & $0.13 \pm 0.12^{\mathrm{a}}$ & $0.3 \pm 0.08^{\mathrm{b}}$ & $0.1 \pm 0.02^{\mathrm{a}}$ \\
MH & $0.1 \pm 0.01^{\mathrm{a}}$ & $0.25 \pm 0.15^{\mathrm{ab}}$ & $0.1 \pm 0.08^{\mathrm{a}}$ \\
MPP & $0.07 \pm 0.01^{\mathrm{a}}$ & $0.2 \pm 0.06^{\mathrm{ab}}$ & $0.08 \pm 0.005^{\mathrm{a}}$ \\
\hline
\end{tabular}

In row and column, the averages affected by the same letter are not significantly different at the $5 \%$ threshold according to the NewmannKeuls test. MH: Haoussabougou market; MPP: Petit Paris market; MG: Major market.

of the "Soumbara" paste is within the range of the moisture content values reported (15-27\%) by Camara et al. [18] in the same product. The water content of food products plays a decisive role during their storage. This is a parameter that significantly affects the conservation and development time of microbial contaminants [19].

In the different markets, the "Soumbara" is sold without any protection. This condiment is sold unpackaged; moreover, the conservation of the unsold "Soumbara" is done in the stores where the temperature of conservation is not
TABle 4: Moisture content of the different types of "Soumbara."

\begin{tabular}{lccc}
\hline Market & Granulated & $\begin{array}{c}\text { Moisture content (\%) } \\
\text { Powder }\end{array}$ & Paste \\
\hline MG & $8.6 \pm 1.15^{\mathrm{a}}$ & $9.3 \pm 3.05^{\mathrm{a}}$ & $24.7 \pm 3.05^{\mathrm{b}}$ \\
MH & $10.7 \pm 2.3^{\mathrm{a}}$ & $7.3 \pm 1.15^{\mathrm{a}}$ & $22 \pm 8.71^{\mathrm{b}}$ \\
MPP & $10.7 \pm 3.05^{\mathrm{a}}$ & $9.3 \pm 2.3^{\mathrm{a}}$ & $20 \pm 3.46^{\mathrm{b}}$ \\
\hline
\end{tabular}

In row and column, the averages affected by the same letter are not significantly different at the 5\% threshold according to the NewmannKeuls test. MH: Haoussabougou market; MPP: Petit Paris market; MG: Major market.

TABLE 5: Loads of mesophilic aerobic germ in the different types of "Soumbara."

\begin{tabular}{lccc}
\hline \multirow{2}{*}{ Market } & \multicolumn{3}{c}{ Mesophilic aerobic germ loads $\left(\log _{10} \mathrm{cfu} / \mathrm{g}\right)$} \\
& Granulated & Powder & Paste \\
\hline MG & $8.38 \pm 1.6^{\mathrm{a}}$ & $7.74 \pm 1.19^{\mathrm{a}}$ & $8.47 \pm 1.6^{\mathrm{a}}$ \\
MH & $7.83 \pm 0.35^{\mathrm{a}}$ & $6.94 \pm 0.82^{\mathrm{a}}$ & $6.76 \pm 0.5^{\mathrm{a}}$ \\
MPP & $6.41 \pm 0.45^{\mathrm{a}}$ & $7.47 \pm 0.76^{\mathrm{a}}$ & $6.17 \pm 0.9^{\mathrm{a}}$ \\
Limit $(M)$ & $\mathbf{6}$ & $\mathbf{6}$ & $\mathbf{6}$ \\
\hline
\end{tabular}

In row and column, the averages affected by the same letter are not significantly different at the $5 \%$ threshold according to the NewmannKeuls test. MH: Haoussabougou market; MPP: Petit Paris market; MG: Major market.

respected. All these bad practices could influence the microbiological contamination level of this condiment in the markets.

All mesophilic aerobic germ loads for the three types of "Soumbara" in this study are higher than the guide value of $6 \log _{10} \mathrm{cfu} / \mathrm{g}$, indicating an unsatisfactory microbiological quality of the different samples. Lack of personnel hygiene, storage in improper conditions, and prolongation of the 
TABLE 6: Loads of total coliforms in the different types of "Soumbara."

\begin{tabular}{lccc}
\hline \multirow{2}{*}{ Market } & \multicolumn{3}{c}{ Total coliforms loads $\left(\log _{10} \mathrm{cfu} / \mathrm{g}\right)$} \\
& Granulated & Powder & Paste \\
\hline MG & $1.71 \pm 1.54^{\mathrm{a}}$ & $2.47 \pm 0.89^{\mathrm{a}}$ & $1.64 \pm 2.2^{\mathrm{a}}$ \\
MH & $1.76 \pm 2.11^{\mathrm{a}}$ & $1.86 \pm 0.57^{\mathrm{a}}$ & $1.26 \pm 0.47^{\mathrm{a}}$ \\
MPP & $2.25 \pm 2.26^{\mathrm{a}}$ & $2.96 \pm 0.68^{\mathrm{a}}$ & $1.13 \pm 1.06^{\mathrm{a}}$ \\
Limit $(M)$ & 3 & 3 & 3 \\
\hline
\end{tabular}

In row and column, the averages affected by the same letter are not significantly different at the $5 \%$ threshold according to the NewmannKeuls test. MH: Haoussabougou market; MPP: Petit Paris market; MG: Major market.

TABLE 7: Loads of mould in the different types of "Soumbara".

\begin{tabular}{lccc}
\hline \multirow{2}{*}{ Market } & \multicolumn{3}{c}{ Mould loads $\left(\log _{10}\right.$ cfu/g) } \\
& Granulated & Powder & Paste \\
\hline MG & $2.4 \pm 0.69^{\mathrm{a}}$ & $2.25 \pm 0.27^{\mathrm{a}}$ & $1.56 \pm 0.51^{\mathrm{a}}$ \\
MH & $1.2 \pm 1.15^{\mathrm{a}}$ & $1.78 \pm 1,58^{\mathrm{a}}$ & $2.52 \pm 0.77^{\mathrm{a}}$ \\
MPP & $1.44 \pm 0.42^{\mathrm{a}}$ & $1.76 \pm 0.4^{\mathrm{a}}$ & $0.86 \pm 0.8^{\mathrm{a}}$ \\
Limit $(M)$ & 4 & 4 & 4 \\
\hline
\end{tabular}

In row and column, the averages affected by the same letter are not significantly different at the $5 \%$ threshold according to the NewmannKeuls test. MH: Haoussabougou market; MPP: Petit Paris market; MG: Major market.

TABLE 8: Loads of yeast in the different types of "Soumbara."

\begin{tabular}{lccc}
\hline \multirow{2}{*}{ Market } & \multicolumn{3}{c}{ Yeast $\operatorname{loads}\left(\log _{10}\right.$ cfu/g) } \\
& Granulated & Powder & Paste \\
\hline MG & $<1$ & $<1$ & $<1$ \\
MH & $0.33 \pm 0.57^{\mathrm{a}}$ & $0.56 \pm 0.98^{\mathrm{a}}$ & $<1$ \\
MPP & $1.15 \pm 0.27^{\mathrm{a}}$ & $1.53 \pm 0.5^{\mathrm{a}}$ & $0.75 \pm 1.3^{\mathrm{a}}$ \\
Limit $(M)$ & 4 & 4 & 4 \\
\hline
\end{tabular}

In row and column, the averages affected by the same letter are not significantly different at the $5 \%$ threshold according to the NewmannKeuls test. MH: Haoussabougou market; MPP: Petit Paris market; MG: Major market.

storage period due to delay in its sale could be at the origin of these high loads. This result corroborates that of Kambire et al. [16]. The variance of loads between the three types of "Soumbara" is not significant. However, it must be stressed that the mesophilic aerobic germ loads for the three types of "Soumbara" of the major market are the most important. These important loads recorded in this market would be due to the high traffic in this market compared to the other two. According to Kasse et al. [20], the variability in mesophilic aerobic germ from one vendor to another could depend on the density of street traffic, which influences environmental hygiene and therefore product contamination. High loads of mesophilic aerobic germs would favour a strong alteration of the product (merchantable quality) thus generating economic losses.

The presence of total coliforms in the different types of "Soumbara" would be due to a lack of hygiene during production and marketing, but also to the conditions of conser- vation. Total coliform loads are almost identical to those reported by Somda et al. [21] but are higher than the results of Parkouda et al. [17]. However, they are lower than the guide value of $3 \log _{10} \mathrm{cfu} / \mathrm{g}$.

Mould loads are higher than yeast loads but lower than the guide value $\left(4 \log _{10} \mathrm{cfu} / \mathrm{g}\right)$. This result differs from that of Degnon et al. [22], who found no mould loads in the "afitin" a condiment similar to "Soumbara." Fungi are ubiquitous microorganisms that can grow on a wide variety of substrates. Contamination could take place during the processing of African locust bean seeds, marketing, and storage. Moulds are capable of producing mycotoxins in food products. Dabire et al. [10] detected the presence of aflatoxin B2 in samples of "Soumbara" sold in Burkina Faso.

Overall, the microorganism loads of powdered "Soumbara" form are the highest, followed by the loads of granulated "Soumbara" form and finally paste "Soumbara" form despite its higher moisture content than the other two. The level of contamination would be more related to daily contamination and to the format of the "Soumbara." Indeed, the "Soumbara" powder has a large contact surface for contamination and is easily mixed compared to the other two.

\section{Conclusion}

The objective of this study was to carry out a microbiological and physicochemical characterisation of three formats of "Soumbara" sold in the markets of Korhogo. The results of this study show that the microbiological quality of the three formats of "Soumbara" sold in Korhogo is unsatisfactory. Mesophilic aerobic germs are responsible for this unsatisfactory result. These microorganisms could degrade this condiment by altering the taste, the smell, and the aspect, in sum the merchantability of the "Soumbara." Overall, the level of contamination is higher in "Soumbara" powder. This format is most often used in food without any cooking. The consumer must add the "Soumbara" during the cooking of the meals. Producers and sellers should adopt adequate hygienic conditions to preserve the safety of this condiment.

\section{Data Availability}

Data used to support the findings of this study are included within the article.

\section{Conflicts of Interest}

The authors declare that there are no conflicts of interest regarding the publication of this paper.

\section{Acknowledgments}

The authors would like to thank the "Soumbara" sellers and Mr. Coulibaly, laboratory technician, for his help during the laboratory work.

\section{References}

[1] N. Robert, D. J. Hounhouigan, and V. B. Tiny, les Aliments Transformation, Conservation et Qualité, Backhauys 
Publishers, Leiden, the Netherlands co-Production with"Centre Technique de Coopération Agricole (CTA), 2003.

[2] E. Cheyns and N. Bricas, "La construction de la qualité des produits alimentaires: le cas du soumbala, des céréales et des viandes sur le marché de Ouagadougou au Burkina Faso = Food product quality development processes," in Case Studies on Soumbala, Cereal and Meat Products on the Ouagadougou Market, p. 82, Montpellier: CIRAD, 2003, (Série ALISA).

[3] S. Koné, Fabrication du "Sumbala", Gate Information Service, Food processing Field, p. 8, 2001.

[4] P. Azokpota, H. Y. Houngbo, and N. H. Akissoe, "Stabilizing behaviour of traditional additives used for afitin storage, an African locust bean-based condiment (Parkia biglobosa Jack. P. Br)," Cahiers Agricultures, vol. 20, no. 6, pp. 494-499, 2011.

[5] K. Koura, P. I. G. Ouidoh, P. Azokpota, J. C. Ganglo, and D. J. Hounhouigan, "Caractérisation physique et composition chimique des graines de Parkia biglobosa (Jacq.) R. Br. En usage au Nord-Bénin," Journal of Applied Bioscience, vol. 75, no. 1, pp. 6239-6249, 2014.

[6] P. AZOKPOTA, D. HOUNHOUIGAN, and M. NAGO, "Microbiological and chemical changes during the fermentation of African locust bean (Parkia biglobosa) to produce afitin, iru and sonru, three traditional condiments produced in Benin," International Journal of Food Microbiology, vol. 107, no. 3, pp. 304-309, 2006.

[7] P. O. Uaboi-Egbenni, P. N. Okolie, A. O. Sobande, O. Alao, O. Teniola, and P. O. Bessong, "Identification of subdominant lactic acid bacteria in dawadawa (a soup condiment) and their evolution during laboratory-scale fermentation of Parkia biglobosa (African locust beans)," African Journal of Biotechnology, vol. 8, no. 25, pp. 7241-7248, 2009.

[8] O. A. Ajayi, I. M. Akinrinde, and O. O. Akinwunmi, "Towards the development of shelf stable 'iru' (Parkia biglobosa) condiment bouillon cubes using corn, cassava and potato starch extracts as binders," Nigerian Food Journal, vol. 33, no. 1, pp. 67-72, 2015.

[9] A. S. Roukaya, O. D. Halima, S. A. Alio, Y. Bakasso, and B. Abdourahamane, "Caractérisation biochimique et microbiologique de Soumbala de néré (Parkia biglobosa) et d'oseille de Guinée (Hibiscus sabdariffa) produits au Niger," European Scientific Journal, vol. 16, no. 3, pp. 224-243, 2020.

[10] D. Yérobessor, M. Iliassou, K. S. Marius et al., "Production technique, safety and quality of soumbala, a local food condiment sold and consumed in Burkina Faso," African Journal of Food Science, vol. 14, no. 2, pp. 38-52, 2020.

[11] D. De Angelis, Y. E. Madodé, A. Briffaz, D. J. Hounhouigan, A. Pasqualone, and C. Summo, "Comparing the quality of two traditional fried street foods from the raw material to the end product: the Beninese cowpea-based ata and the Italian wheat-based popizza," Legume Science, vol. 2, no. 2, pp. 1-10, 2020.

[12] E. B. Z. N'goran-Aw, D. Soro, S. Aw, K. D. Akaki, and N. E. Assidjo, "Evaluation des caracteristiques physico-chimiques et microbiologiques d'un beignet traditionnel à base de mil fermente (Gnomy) commercialise dans la ville de Yamoussoukro (Côte d'Ivoire)," European Scientific Journal, vol. 13, no. 9, pp. 227-241, 2017.

[13] W. K. Amoa-awua, E. Sampson, and K. Tano-Debrah, "Growth of yeasts, lactic and acetic acid bacteria in palm wine during tapping and fermentation from felled oil palm (Elaeis guineensis) in Ghana," Journal of Applied Microbiology, vol. 102, no. 2, pp. 599-606, 2006.
[14] AOAC (Association of Official Analytical Chemists), Official Methods of Analysis, Association of Official Analytical Chemists, Washington DC, 1990.

[15] ISO 7218, Microbiologie des Aliments-Exigences Générales et Recommandations, 76, 3rd edition, 2007.

[16] O. Kambire, Z. I. A. Boli, K. M. Yao, D. M. P. Ahipo, and R. Koffi-Nevry, "Microbiological quality of "Soumbala", an African locust bean (Parkia biglobosa) condiment sold in the markets of Abidjan, Côte d'Ivoire," Journal of Advances in Microbiology, vol. 20, no. 10, pp. 67-74, 2020.

[17] C. Parkouda, F. Ba/Hama, L. Ouattara/Songre, K. Tano-Debrah, and B. Diawara, "Biochemical changes associated with the fermentation of baobab seeds in Maari: an alkaline fermented seeds condiment from western Africa," Journal of Ethnic Foods, vol. 2, no. 2, pp. 58-63, 2015.

[18] F. Camara, S. Soronikpoho, T. Souleymane, B. Kouakou, and J. K. Marcellin, "Caractéristiques biochimiques et microbiologiques de moutardes africaines produites à base de graines fermentées de Parkia biglobosa et de Glycine max, vendues en Côte d'Ivoire," International Jounal of Biological and Chemical Sciences, vol. 10, no. 2, pp. 506-518, 2006.

[19] A. A. Siddiqui and M. N. Chowdhury, "Physico-chemical and microbiological quality assessment of different popular brands of wheat flour, available in Bangladesh," Journal of SUB, vol. 4, pp. 57-65, 2013.

[20] M. Kasse, M. Cisse, A. Toure, M. N. Ducamp-collin, and M. Guisse, "Qualité microbiologique des tranches de mangues (Mangifera indica L.) vendues à Dakar (Sénégal)," International Journal of Biological and Chemical Sciences, vol. 8, no. 4, pp. 1611-1619, 2014.

[21] M. K. Somda, A. Savadogo, F. Tapsoba, N. Ouédraogo, C. Zongo, and A. S. Traoré, "Impact of traditional process on hygienic quality of soumbala a fermented cooked condiment in Burkina Faso," Journal of Food Security, vol. 2, no. 2, pp. 59-64, 2014.

[22] R. G. Degnon, C. T. R. Konfo, K. Aboudou, and Y. M. G. G. Bagbonon, "Influence de la variété sur les caractéristiques microbiologiques, physico-chimiques et sensorielles du afitin, un condiment produit à base de graines de soja au Bénin," International Journal of Innovation and Applied Studies, vol. 29, no. 4, pp. 1153-1160, 2020. 